\title{
Soot formation and oxidation during bio-oil gasification: experiments and modeling
}

\author{
Younes Chhiti $^{\mathrm{a} *}$, Marine Peyrot $^{\mathrm{b}}$, Sylvain Salvador ${ }^{\mathrm{c}}$ \\ a. LEGI, UJF-Grenoble 1/Grenoble-INP/CNRS, BP 53, Grenoble, F-38041, France; \\ b. CEA/DRT/LITEN/DTBH/LTB Laboratoire des Technologies pour la Biomasse 17, rue de Martyrs 38054, Grenoble, France; \\ c. Ecole des Mines d'Albi-Carmaux, Centre RAPSODEE, FRE CNRS 3213, Campus Jarlard, route de Teillet 81013, Albi, France \\ [ Manuscript received February 8, 2013; revised April 2, 2013]
}

\begin{abstract}
A model is proposed to describe soot formation and oxidation during bio-oil gasification. It is based on the description of bio-oil heating, devolatilization, reforming of gases and conversion of both char and soot solids. Detailed chemistry (159 species and 773 reactions) is used in the gas phase. Soot production is described by a single reaction based on $\mathrm{C}_{2} \mathrm{H}_{2}$ species concentration and three heterogeneous soot oxidation reactions. To support the validation of the model, three sets of experiments were carried out in a lab-scale Entrained Flow Reactor (EFR) equipped with soot quantification device. The temperature was varied from 1000 to $1400{ }^{\circ} \mathrm{C}$ and three gaseous atmospheres were considered: default of steam, large excess of steam $\left(\mathrm{H}_{2} \mathrm{O} / \mathrm{C}=8\right)$, and the presence of oxygen in the $\mathrm{O} / \mathrm{C}$ range of $0.075-0.5$. The model is shown to accurately describe the evolution of the concentration of the main gas species and to satisfactorily describe the soot concentration under the three atmospheres using a single set of identified kinetic parameters. Thanks to this model the contribution of different mechanisms involved in soot formation and oxidation in various situations can be assessed.
\end{abstract}

Key words

soot; gasification; pyrolysis; partial oxidation; bio-oil

\section{Introduction}

Due to continuous decrease in the amount and availability of conventional fossil fuels, it is becoming inevitable to search for new fuel sources. The renewable nature of biomass places it among the most attractive options. Using biomass as renewable feedstock would strongly contribute to decreasing greenhouse gas emissions due to neutral $\mathrm{CO}_{2}$ balance. From a technical point of view, biomass feedstocks can be transformed into sustainable syngas $\left(\mathrm{H}_{2}+\mathrm{CO}\right)$ or hydrogen by thermo chemical processes like gasification which includes several methods such as steam reforming (SR), partial oxidation (POX), and oxidative steam reforming (OSR) [1-3].

Soot formation is a major problem to face with in biomass thermal conversion. In a combustion process, soot formation results from incomplete combustion and typically occurs at fuel-rich stoichiometries. Soot formation is an active field of combustion research. This is not only because it remains a challenge from a fundamental point of view, but also because combustion-generated soot particles have serious environmental effects [4]. They are also associated with health risks since both polycyclic aromatic hydrocarbons (PAHs) that are precursors of soot and soot-associated organics have been identified to be carcinogenic. Moreover, soot may be a problem during operation of engines because it can lead to solid deposits [5].

Thus, the control of soot emission from combustion or gasification processes is a crucial issue that needs to be solved to avoid problems of deposits, to ensure syngas purity and to reduce harmful impacts to humans and the environment. Quantitative prediction of soot growth and subsequent oxidation mechanisms are critical to the development of approaches to control soot emissions [6,7]. Soot is produced in pyrolysis and combustion/gasification systems when conditions are such as to allow gas-phase condensation reactions of the fuel. The most accepted simple theory for soot formation is well described by Haynes and Wagner [8]. They assert that the pyrolysis of hydrocarbons produces smaller hydrocarbons, and in particular acetylene. The initial step is the formation of the first aromatic species from the aliphatic hydrocarbons, followed by the addition of other aromatic and alkyl species to give higher species, i.e. Polyaromatic Hydrocarbons (PAH). The continued growing of these PAHs results in the generation of small soot particles. In soot formation modeling, several principle proposals are known, which describe the nature of soot particle inception. According to them, different types of species are ranged as potential precursors, leading to soot

\footnotetext{
*Corresponding author. Tel: +33(6)60425664; E-mail: chhiti.younes@gmail.com
} 
particle inception e.g., polyacetylenes or polyynes [9-12], and polycyclic aromatic hydrocarbons [13-16]. To model such a chemical process, it is desirable to use detailed chemical kinetic mechanisms including up to $\mathrm{C}_{6}$ species, for example, the HACA-mechanism [17] and the extended HACAmechanism [18]. An alternative approach for soot modeling is to use a semi-empirical model. The soot semi-empirical model here proposed is based on $\mathrm{C}_{2} \mathrm{H}_{2}$ as the precursor.

Until now, most experimental studies of sooting processes have been focused on fossil fuel combustion in diesel engines, and in diffusion flames. Thus, there are very few available data on soot formation from biomass and from bio-oil. The purpose of this paper is to propose a model able to describe as simply as possible the formation and the oxidation of soot during thermal conversion of bio-oil. The model is expected to describe the effect of temperature on soot formation and destruction over the range of $1000-1400{ }^{\circ} \mathrm{C}$ in three different kinds of atmosphere: inert, $\mathrm{H}_{2} \mathrm{O}$ enriched and $\mathrm{O}_{2}$ containing.

\section{Experimental}

\subsection{Description of experimental device}

Experiments were carried out in a laboratory scale En- trained Flow Reactor (EFR). It consisted in a vertical tubular reactor electrically heated by a total of $18 \mathrm{~kW}$ three-zone electrical furnace, and was able to reach $1600{ }^{\circ} \mathrm{C}$ in a $1 \mathrm{~m}$ long isothermal reaction zone, as illustrated in Figure 1. The atmosphere gas was generated by feeding the controlled flows of nitrogen in a $2 \mathrm{~kW}$ electrical steam generator. This atmosphere gas was then preheated at $900^{\circ} \mathrm{C}$ using a $2.5 \mathrm{~kW}$ electrical battery of heating elements before reaching the isothermal reaction zone. The EFR was equipped with a specially designed bio-oil spraying feeder. The feeder consisted of a $1 \mathrm{~m}$ long and $14 \mathrm{~mm}$ o.d. probe cooled with water at $30{ }^{\circ} \mathrm{C}$. At its extremity a stainless steel nozzle was integrated, which allowed uniform distribution with fine atomization. The microscopic observation of droplets impacted on a surface indicates a size ranging between 10 and $100 \mu \mathrm{m}$. However, the majority of the droplets were much smaller and not observable.

The oil was fed with a syringe which is pushed automatically. The expected mass flowrate of $0.3 \mathrm{~g} \cdot \mathrm{min}^{-1}$ was too low for direct spraying. Therefore, a $3.5 \mathrm{NL} \cdot \mathrm{min}^{-1} \mathrm{~N}_{2}$ flowrate was used to entrain oil in the feeding probe and to ensure a thin spray of the oil. The spray of droplets was dispersed on the section of the $75 \mathrm{~mm}$ i.d. alumina reactor swept by $15 \mathrm{NL} \cdot \mathrm{min}^{-1}$ of atmosphere gas. At $1760 \mathrm{~mm}$ downstream of the injection point, gas and solid residue were sampled by a

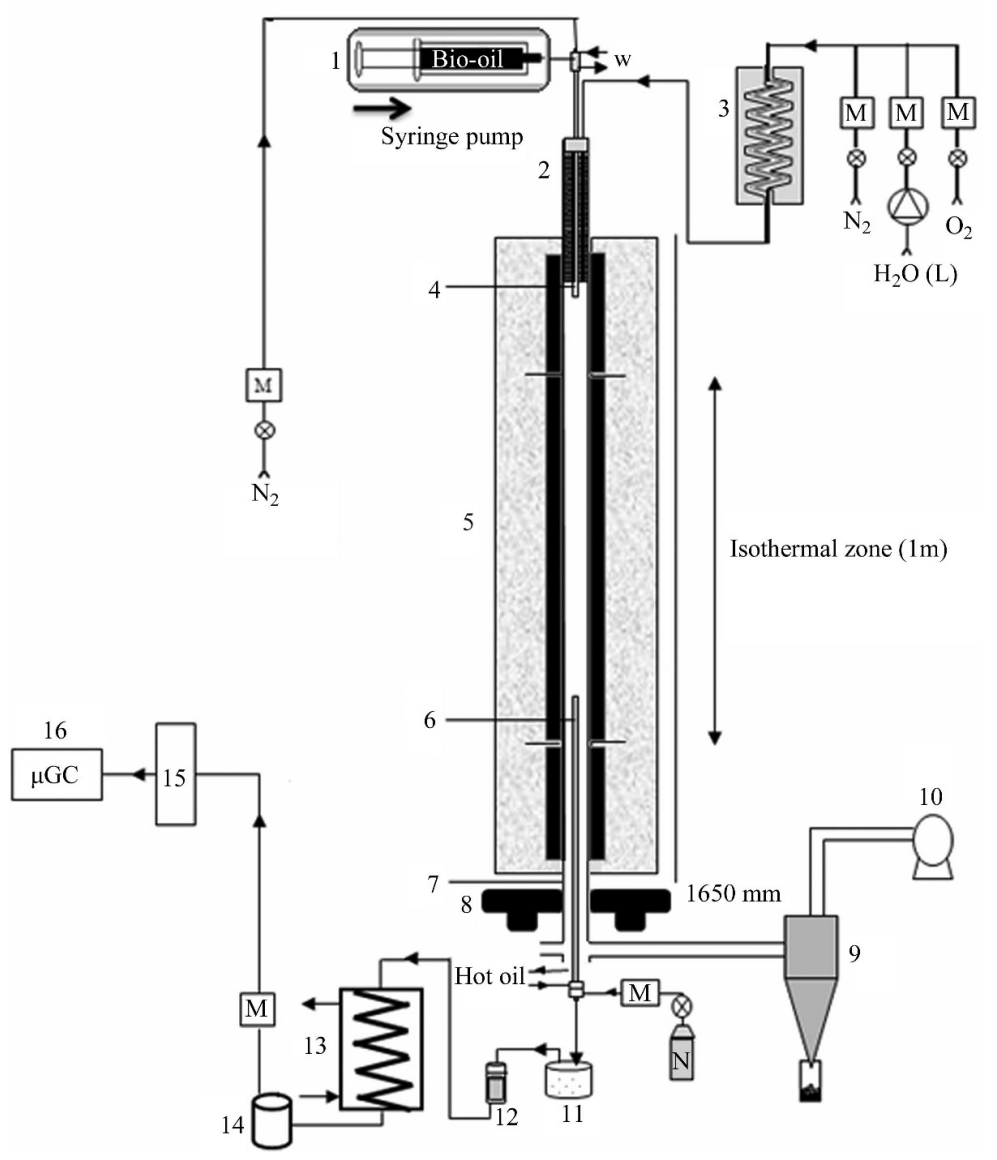

Figure 1. Scheme of the entrained flow reactor (EFR). 1-Injection system, 2-Electrical preheater, 3-Steam generator, 4-Water cooled feeding probe, 5Three zones electrical furnace, 6-Oil cooled sampling probe, 7-75 mm i.d. alumina reactor, 8-Soot quatification device, 9-Cyclone collector, 10-Exhaust fan, 11-Hot settling box, 12-Hot particle collector (filter), 13-Water cooler, 14—Condensate collector, 15-Gas dryer, 16-Gas analyser; M-Mass flow meters and controllers, W-Water (feeder cooling) 
hot-oil cooled probe. The injected atmosphere gas flowrate and the sampled gas flowrate were accurately measured using mass flow meters/controllers. Gas and solid residue were separated using a settling box and a filter, both heated to avoid water condensation. The water and potential remaining tar were first condensed in a heat exchanger, and noncondensable gases were forwarded to a micro-chromatograph analyser (GC) to quantify $\mathrm{H}_{2}, \mathrm{CO}, \mathrm{CO}_{2}, \mathrm{CH}_{4}, \mathrm{C}_{2} \mathrm{H}_{2}, \mathrm{C}_{2} \mathrm{H}_{4}$, $\mathrm{C}_{2} \mathrm{H}_{6}, \mathrm{C}_{3} \mathrm{H}_{8}$ and $\mathrm{C}_{6} \mathrm{H}_{6}$.

Laser extinction was used to make quantitative measurements of soot content in the produced gas. The optical thickness can be quantitatively related to the soot volumetric fraction through a linear relation. The coefficient associated to this relation was experimentally determined.

\subsection{Feedstock}

The feedstock used for all experiments was bio-oil produced by fast pyrolysis of mixture of hardwood (oak, maple and ash) in an industrial-scale fluidized-bed unit (Dynamotive, West Lorne, Ontario) and provided by CIRAD, France. Its physico-chemical properties have been measured (see Table 1). The water content of the bio-oil measured by Karl Fischer method (ASTM E203) is around $26 \mathrm{wt} \%$ which is in agreement with the average values reported in literature. It can be noticed that the solid particles content is rather high $(2.3 \mathrm{wt} \%)$ while the ash content remains very low (around $0.06 \mathrm{wt} \%$ ). This confirms that the solid particles mainly consist of high-carbon content char particles. These particles were entrained during bio-oil production by the gas stream to the bio-oil condensers. Ultimate analysis and LHV of the biooil are very similar to those of wood. From the ultimate analysis, the chemical formula of the bio-oil can be established as $\mathrm{CH}_{1.18} \mathrm{O}_{0.48} \cdot 0.4 \mathrm{H}_{2} \mathrm{O}$.

After the production, the bio-oil was stored at $5{ }^{\circ} \mathrm{C}$ in a fridge. Before experiments, it was filtered on a $30 \mathrm{~m}$ sieve to eliminate the largest solid particles which accounted for less than $0.01 \mathrm{wt} \%$ of the oil.

Table 1. Ultimate analysis and physico-chemical properties of bio-oil derived from hardwood fast pyrolysis

\begin{tabular}{|c|c|c|c|c|c|c|c|c|}
\hline \multicolumn{4}{|c|}{ Ultimate analysis (wt\%) } & \multirow{2}{*}{$\begin{array}{r}\mathrm{H}_{2} \mathrm{O} \\
(\mathrm{wt} \%) \\
\end{array}$} & \multirow{2}{*}{$\begin{array}{c}\text { Ash } \\
(\mathrm{wt} \%)\end{array}$} & \multirow{2}{*}{$\begin{array}{l}\text { Solids } \\
(\mathrm{wt} \%) \\
\end{array}$} & \multirow{2}{*}{$\begin{array}{c}\text { LHV } \\
(\mathrm{MJ} / \mathrm{kg})\end{array}$} & \multirow{2}{*}{$\begin{array}{l}\text { Kinematic viscosity } \\
\text { at } 20^{\circ} \mathrm{C}\left(\mathrm{mm}^{2} \cdot \mathrm{s}^{-1}\right)\end{array}$} \\
\hline $\mathrm{C}$ & $\mathrm{H}$ & $\mathrm{O}$ & $\mathrm{N}$ & & & & & \\
\hline 42.9 & 7.1 & 50.58 & $<0.10$ & 26.0 & 0.057 & 2.34 & 14.5 & 103 \\
\hline
\end{tabular}

\subsection{Model description and parameter setting}

The GASPAR software computes the gasification of a solid spherical particle in a gaseous environment in Entrained Flow Reactor conditions. GASPAR has been developed successively by Van de Steene, Commandré, Cancès and Peyrot [19-22]. A one-dimensional (1D) laminar plug flow reactor is assumed in the model based on a Lagrangian approach. The whole flow is simulated considering a single particle, with possible distribution of particles of various diameters, and the associated gas volume. This particle and the gas volume sample constitute elementary part of the EFR's flow. The model simulates the time evolution of this sample along the reactor. The model is able to predict the evolution of several variables versus gas residence, namely, gas phase temperature, particle temperature, particle mass, gas species concentrations, soot yield and tar yield. All the differential equations are simultaneously time integrated through the Gear algorithm that can solve "stiff" ODE systems [23]. The whole model is included in a FORTRAN program.

For the present contribution, bio-oil droplets gasification is simulated as if droplets were solid particles. The droplets diameter is of about $10 \mu \mathrm{m}$. For such size, internal heat transfer can be neglected and the particle was considered as isothermal. The slip velocity between particle and gas can also be neglected here.

The GASPAR model is used here with the aim to describe soot formation and oxidation during gasification. It is based on the description of gas phase and bio-oil heating (radiative, conductive and convective heat transfer), bio-oil devolatilization, gas reforming and conversion of both char and soot solids. The gas phase reactions are computed using subroutines from the CHEMKIN II software [24]. For the present contribution, the chemical scheme used is the SkjøthRasmussen scheme (159 species, and 773 reactions) [25]. This model can also predict tar compounds evolution. Naphthalene has been taken as the reference compound to calculate tars in devolatilization products; this compound enters the detailed gas phase reactions. In the model, char can be oxidized via three heterogeneous reactions with $\mathrm{O}_{2}, \mathrm{H}_{2} \mathrm{O}$ and $\mathrm{CO}_{2}$. Char conversion is modelled with the into-particle diffusion model where the chemical kinetics and the transport phenomena are taken into account through the Thiele diffusion modulus [26].

A four-step soot formation and oxidation model performs the soot computations using the mechanism:

$$
\begin{gathered}
\mathrm{C}_{2} \mathrm{H}_{2} \longrightarrow 2 \mathrm{C}(\text { soot })+\mathrm{H}_{2} \quad \text { Soot formation } \\
\mathrm{C}(\text { soot })+0.5 \mathrm{O}_{2} \longrightarrow \mathrm{CO} \text { Soot oxidation } \\
\mathrm{C}(\text { soot })+\mathrm{H}_{2} \mathrm{O} \longrightarrow \mathrm{CO}+\mathrm{H}_{2} \quad \text { Soot gasification by } \mathrm{H}_{2} \mathrm{O} \\
\mathrm{C}(\text { soot })+\mathrm{CO}_{2} \longrightarrow 2 \mathrm{CO} \text { Soot gasification by } \mathrm{CO}_{2}
\end{gathered}
$$

\subsection{Experimental conditions}

The operating temperature was varied over the range of $1000-1400^{\circ} \mathrm{C}$. Gas atmosphere was preheated at $900^{\circ} \mathrm{C}$ for all experiments. Bio-oil was then continuously fed by a feeding probe and injected into the reactor tube through a nozzle 
by a nitrogen stream. The feeding rate of feedstock was of $0.3 \mathrm{~g} / \mathrm{min}$ as explained previously, and three gaseous atmospheres were considered.

Firstly, the simplest situation of pyrolysis, i.e. in an inert atmosphere, was studied. In this case, the reactions involved are devolatilization, cracking, and some reforming and gasification by $\mathrm{H}_{2} \mathrm{O}$ that is present in the fed bio-oil.

Secondly, excess of $\mathrm{H}_{2} \mathrm{O}$ called steam gasification was studied. Gasification tests were carried out by supplying a mixed stream of nitrogen with steam. The steam to carbon molar ratio was $\mathrm{S} / \mathrm{C}=8.3$ which was equivalent to $10 \mathrm{vol} \%$ of steam in the atmosphere gas.

Lastly, the presence of $\mathrm{O}_{2}$ was explored. The so-called partial oxidation tests were carried out by supplying a mixture stream of nitrogen with $\mathrm{O}_{2}$. The amount of $\mathrm{O}_{2}$ was varied from very small amount to investigate a potential impact through radicals $(\mathrm{O} / \mathrm{C}=0.075)$, to large amount that may oxidize a significant part of bio-oil $(\mathrm{O} / \mathrm{C}=0.5)$. This is equivalent to $0.1-0.75 \mathrm{vol} \%$ of oxygen in atmosphere gas.

\section{Results and discussions}

In the following section, the yield of each main product is investigated separately. The experimental values are considered at first.

\subsection{Profiles of product gas}

Figure 2(a) shows gas species molar fractions at the bottom of the reactor versus temperature for pyrolysis, steam gasification and partial oxidation processes; Figure 2(b) plots gas species molar fractions at the bottom of the reactor versus $\mathrm{O} / \mathrm{C}$ molar ratio for partial oxidation process at the temperature of $1200^{\circ} \mathrm{C}$.

\subsection{1. $\mathrm{H}_{2}$ production}

The production of $\mathrm{H}_{2}$ increased with temperature in all cases. The yields of $\mathrm{H}_{2}$ in the exit gas varied in the order of steam gasification $>$ pyrolysis $>$ partial oxidation.

In the case of pyrolysis process, $\mathrm{H}_{2}$ is thought to be mainly generated from the dehydrogenation (through the cleavage of $\mathrm{C}-\mathrm{H}$ or $\mathrm{O}-\mathrm{H}$ bond) of chemical compounds of bio-oil, and from the secondary decomposition of their pyrolyzed products (tars and hydrocarbon gas). Water contained by bio-oil can cause reforming reactions and favor the increase of $\mathrm{H}_{2}$ with temperature.

In the presence of steam excess, the production of $\mathrm{H}_{2}$ can be enhanced through steam gasifications of carbon (Equation 5) and condensable volatiles (Equation 6). The water-gas shift reaction can also contribute to the production of $\mathrm{H}_{2}$ (Equation 7):

Carbon gasification

$$
\mathrm{C}+\mathrm{H}_{2} \mathrm{O} \longrightarrow \mathrm{CO}+\mathrm{H}_{2}
$$

Volatiles steam reforming

$$
\mathrm{C}_{n} \mathrm{H}_{m} \mathrm{O}_{k}+(n-k) \mathrm{H}_{2} \mathrm{O} \longrightarrow n \mathrm{CO}+(n+m / 2-k) \mathrm{H}_{2}
$$

Water gas shift

$$
\mathrm{CO}+\mathrm{H}_{2} \mathrm{O} \longrightarrow \mathrm{CO}_{2}+\mathrm{H}_{2}
$$

Both reactions (5) and (6) are endothermic, while reaction (7) is exothermic. Thus, high temperature will promote reactions (5) and (6), and low temperature will favor reaction (7) to shift towards the right.

On the other hand, the decrease in $\mathrm{H}_{2}$ yields observed in partial oxidation runs with increasing $\mathrm{O} / \mathrm{C}$ molar ratio suggests that combustion reactions predominate over steam gasification and water-gas shift reaction.

\subsection{2. $\mathrm{CO}$ and $\mathrm{CO}_{2}$ production}

In the case of pyrolysis, $\mathrm{CO}$ and $\mathrm{CO}_{2}$ yields are nearly stable between 1000 and $1200{ }^{\circ} \mathrm{C}$. At higher temperature there is a slight increase in $\mathrm{CO}$ in parallel with a decrease of $\mathrm{CO}_{2}$ which may be explained by Boudouard reaction:

$$
\mathrm{C}+\mathrm{CO}_{2} \longrightarrow 2 \mathrm{CO}
$$

It is known that the production of $\mathrm{CO}$ in the pyrolysis process is mainly attributed to the decomposition of oxygencontaining functional groups in bio-oil.

In the steam gasification case, the water-gas shift reaction may also explain the increase of $\mathrm{CO}_{2}$ and the decrease of $\mathrm{CO}$ between 1000 and $1200^{\circ} \mathrm{C}$. Above $1200^{\circ} \mathrm{C}$, carbon monoxide slightly increases. This may be explained by steam and $\mathrm{CO}_{2}$ gasification of the solid carbon following Reaction (5) and the Boudouard Reaction (8) which would explain the slight decrease of $\mathrm{CO}_{2}$.

On the other hand, unlike the pyrolysis and steam gasification cases, $\mathrm{CO}$ and $\mathrm{CO}_{2}$ formation were significantly enhanced during partial oxidation tests. As $\mathrm{O} / \mathrm{C}$ increases, the $\mathrm{H}_{2}$ yield decreases while $\mathrm{CO}$ and $\mathrm{CO}_{2}$ increase. This was caused by the increased amounts of oxygen which reacted with chemical species containing carbon and hydrogen and gave rise to $\mathrm{CO}_{2}, \mathrm{CO}$ and $\mathrm{H}_{2} \mathrm{O}$ following the reactions:

$$
\begin{gathered}
\mathrm{C}+1 / 2 \mathrm{O}_{2} \longrightarrow \mathrm{CO} \\
\mathrm{C}_{x} \mathrm{H}_{y} \mathrm{O}_{z}+(x / 2-z / 2) \mathrm{O}_{2} \longrightarrow x \mathrm{CO}+(y / 2) \mathrm{H}_{2} \\
\mathrm{C}_{x} \mathrm{H}_{y} \mathrm{O}_{z}+(x+y / 4-z / 2) \mathrm{O}_{2} \longrightarrow x \mathrm{CO}_{2}+(y / 2) \mathrm{H}_{2} \mathrm{O}
\end{gathered}
$$

\subsubsection{Light hydrocarbon gas production}

In Figure 2 only the major hydrocarbons $\mathrm{CH}_{4}$ and $\mathrm{C}_{2} \mathrm{H}_{2}$ are shown. In all cases $\mathrm{CH}_{4}$ is the most abundant species among the light hydrocarbon gases. Its production is maximal at $1000^{\circ} \mathrm{C}$ and then decreases with temperature. It remains in trace amounts at $1300{ }^{\circ} \mathrm{C}$ and is below detection limit at $1400^{\circ} \mathrm{C}$. Its yield is greatly reduced when $\mathrm{O} / \mathrm{C}$ ratio increases, 
which shows that there is some partial oxidation. The trends are similar for $\mathrm{C}_{2} \mathrm{H}_{2}$.

The results of all simulations for the five temperatures $1000,1100,1200,1300$ and $1400{ }^{\circ} \mathrm{C}$ are shown in the same
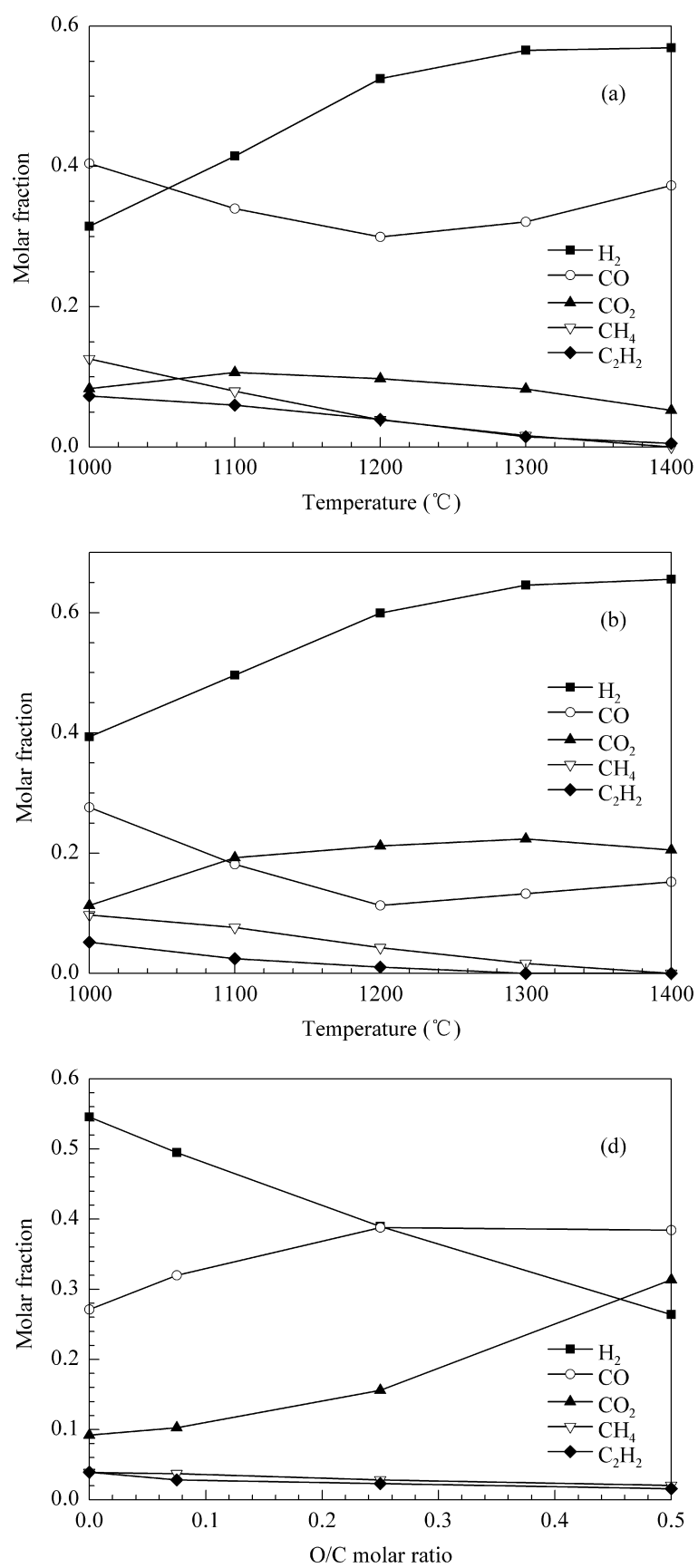

Figures as experiments (Figure $2 \mathrm{a}$ and $2 \mathrm{~b}$ ). As can be observed, the results obtained from the model are in very good agreement with experimental results, except for the $\mathrm{C}_{2} \mathrm{H}_{2}$ specie. This difference will be discussed later.

(c)
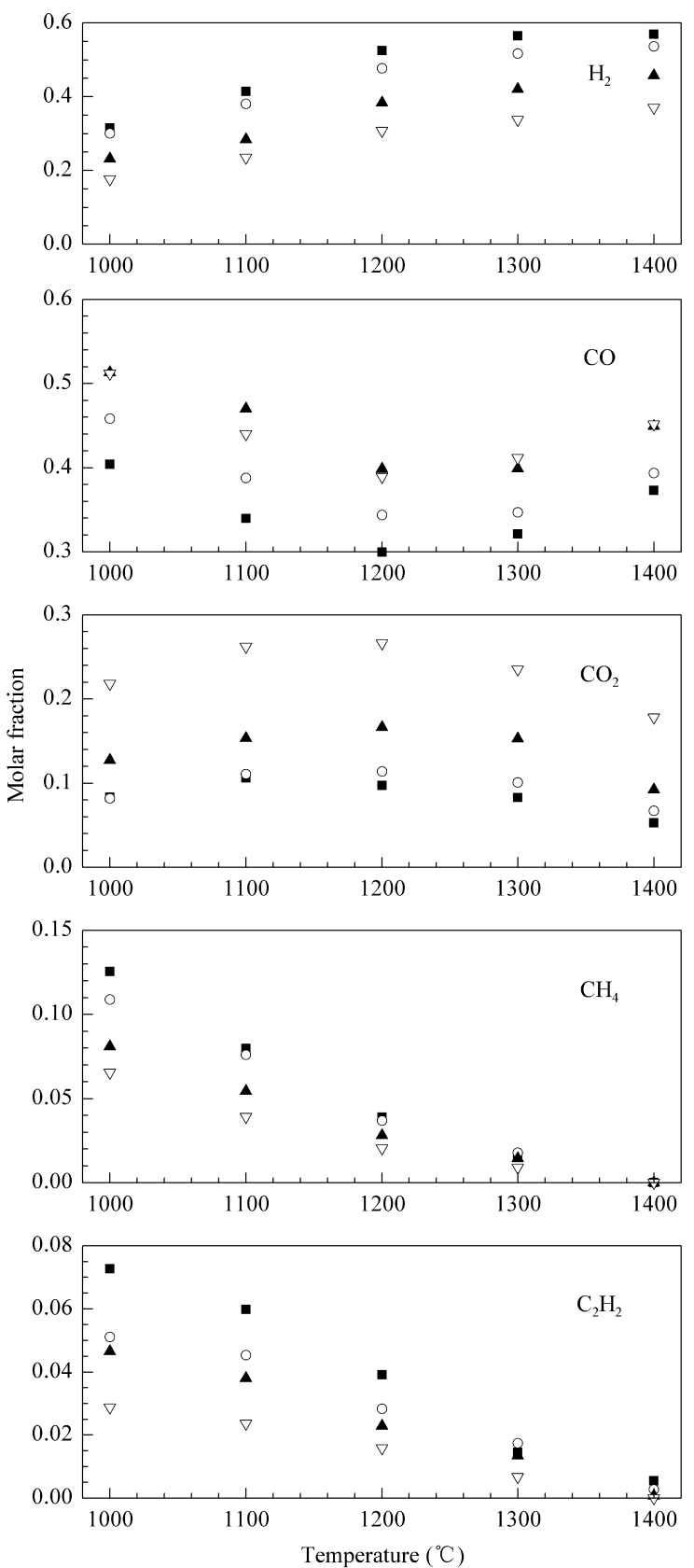

Figure 2. Gas molar fraction versus temperature: (a) pyrolysis case, (b) gasification case, $(\mathrm{c})$ partial oxidation case $(\boldsymbol{\square} \mathrm{O} / \mathrm{C}=0, \circ \mathrm{O} / \mathrm{C}=0.075, \boldsymbol{\Delta} \mathrm{O} / \mathrm{C}=0.25$, $\nabla \mathrm{O} / \mathrm{C}=0.5$ ); and (d) gas molar fraction versus $\mathrm{O} / \mathrm{C}$ molar ratio for partial oxidation process at $1200{ }^{\circ} \mathrm{C}$

\subsection{Soot production}

The results of soot yields obtained in different experiments of pyrolysis, gasification, and partial oxidation are shown in Figures 3(a), 3(b) and 3(c), respectively.
In the case of pyrolysis (Figure 3a), an increase in temperature results in an increase in the soot yield. The increase in soot yield is accompanied by a decrease in the hydrocarbons gas yield as seen previously. This is in agreement with literature results [27-30]. 
The measured soot yield is close to zero at $1000{ }^{\circ} \mathrm{C}$, while important amounts of $\mathrm{C}_{2} \mathrm{H}_{2}$ are present at the exit of the reactor. Above $1000^{\circ} \mathrm{C}$, a strong increase of soot yield with temperature is observed up to $1200{ }^{\circ} \mathrm{C}$ where the soot yield is $3.58 \times 10^{-2} \mathrm{~g} / \mathrm{g}$. The soot yield measured at $1300^{\circ} \mathrm{C}$ and $1400{ }^{\circ} \mathrm{C}$ is only slightly higher. This increase is accompanied by $\mathrm{C}_{2} \mathrm{H}_{2}$ decrease at the exit. The acetylene which is considered as the main soot precursor would react further to produce soot and hydrogen [31].
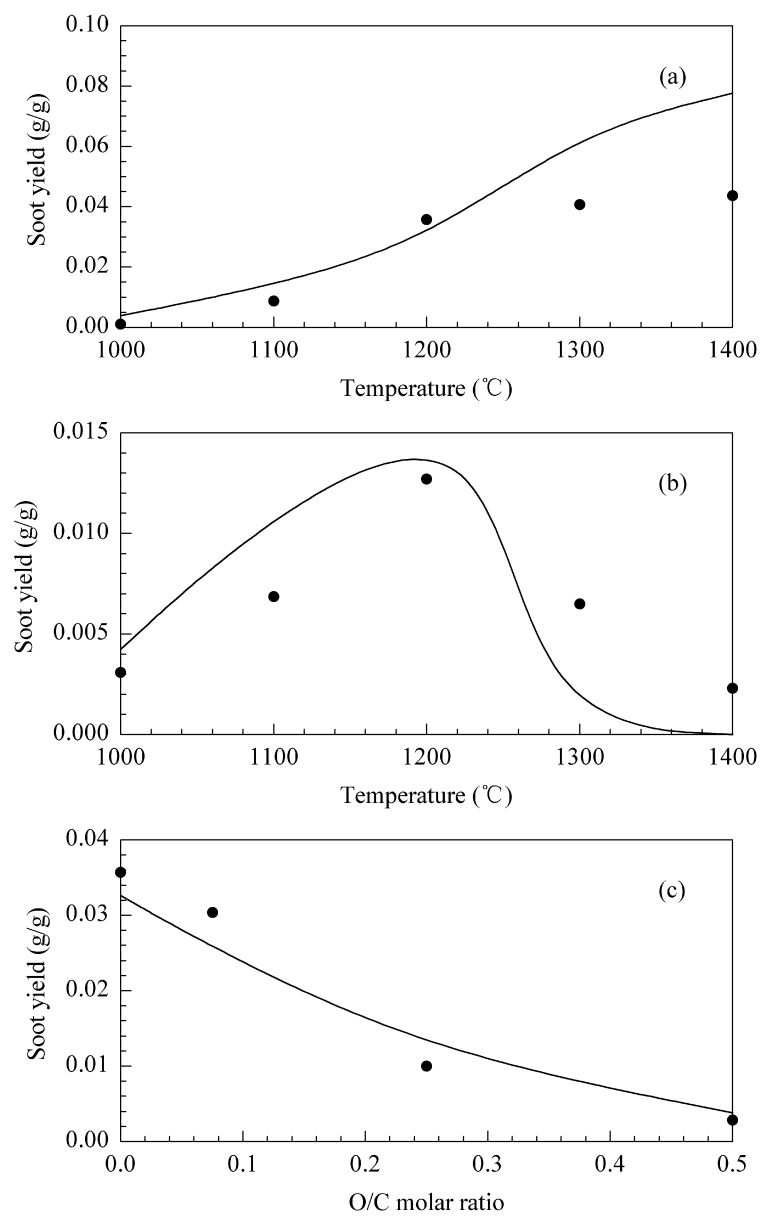

Figure 3. Soot yields versus temperature: (a) pyrolysis case, (b) gasification case. (c) Soot yields versus $\mathrm{O} / \mathrm{C}$ molar ratio at $1200^{\circ} \mathrm{C}$ : Partial oxidation case. Experiments (symbols) and modeling (lines)

The model satisfactorily predicts the soot formation at temperatures between $1000{ }^{\circ} \mathrm{C}$ and $1200{ }^{\circ} \mathrm{C}$ which tends to confirm the role of $\mathrm{C}_{2} \mathrm{H}_{2}$ in soot formation. Above $1200^{\circ} \mathrm{C}$ the model predicts higher yields of soot than experiments. This may result from an incorrect calculation of the $\mathrm{C}_{2} \mathrm{H}_{2}$ gas phase concentration by the reaction mechanism. As can be seen in the product gas figure, the measured and calculated concentrations of acetylene show the same tendencies but with a gap.

In the gasification case, the soot yield is more than 3 times smaller than that in the pyrolysis case, as can be seen in Figure 3(b). The measured and calculated curves are both bellshaped curves, showing that the model correctly describes the trend. At $1000{ }^{\circ} \mathrm{C}$, experiment shows a low soot yield, which gets higher when reaction temperature increases and until the soot yield reaches a maximum of $1.27 \times 10^{-2} \mathrm{~g} / \mathrm{g}$ at about $1200{ }^{\circ} \mathrm{C}$. Above $1200{ }^{\circ} \mathrm{C}$, the soot yield strongly decreases. This decrease may be explained by steam and $\mathrm{CO}_{2}$ gasification of soot following Reaction (5) and following the Boudouard Reaction (8) which would explain the slight decrease of $\mathrm{CO}_{2}$ obtained in Figure 2(a), as well as the increase of $\mathrm{H}_{2}$ and $\mathrm{CO}$.

The limited formation of soot at high temperature due to the presence of water has been reported to result from changes in the radical pool [25]. Steam enhances the formation of hydroxyl radicals, through $\mathrm{H}+\mathrm{H}_{2} \mathrm{O} \leftrightarrow \mathrm{OH}+\mathrm{H}_{2}$, and $\mathrm{OH}$ radicals may oxidize soot and also oxidize with $\mathrm{C}_{2} \mathrm{H}_{2}$ and therefore causes a decrease in the soot production. Water would therefore compete with $\mathrm{C}_{2} \mathrm{H}_{2}$.

In the partial oxidation case, from a thermodynamic point of view, soot formation can occur when fuel-rich conditions are present, i.e. when the $\mathrm{O} / \mathrm{C}$ molar ratio is lower than 1 . In the present experimental investigations the $\mathrm{O} / \mathrm{C}$ molar ratio was varied from 0.075 to 0.5 at $1200{ }^{\circ} \mathrm{C}$, because at this temperature the production of soot is the highest. As can be seen in Figure 3(c), the measured amount of soot strongly decreases with the $\mathrm{O} / \mathrm{C}$ ratio under the conditions explored. This tendency is satisfactorily described by the model. According to the literature, when $\mathrm{O} / \mathrm{C}$ molar ratio increases, most hydrocarbons are destroyed by oxidation or thermal decomposition, and numerous intermediate species are formed. In this way, a competition between the molecular growth and oxidative reactions occurs. Oxidative reactions lead to the formation of various oxygen-containing intermediates and products like $\mathrm{CO}$, $\mathrm{CO}_{2}$, and $\mathrm{H}_{2} \mathrm{O}$. As a result, the soot yield decreases compared with the case of pyrolysis.

\subsection{Discussion: contribution of the model}

In this section the model is used to discuss the results by identifying the contribution of each reaction to soot oxidation in the three situations (pyrolysis, steam gasification, partial oxidation). The prediction of the evolution of the gas species along the reactor also gives important information for understanding the transformation mechanisms.

(a) Pyrolysis situation

Calculations of soot yield are shown in Figure 4 versus temperature when oxidation reaction are activated and deactivated. In pyrolysis situation we note that the activation of the reaction of oxidation by $\mathrm{CO}_{2}$ caused a negligible decrease in the soot yield. This oxidation was of about $3 \%$ at $1400{ }^{\circ} \mathrm{C}$. Activation of the reaction with water has no effect at $1200^{\circ} \mathrm{C}$. However it causes a soot yield decrease of $26 \%$ at $1400{ }^{\circ} \mathrm{C}$.

Figure 5 shows the profile of soot yield and $\mathrm{C}_{2} \mathrm{H}_{2}$ volumetric fraction along the reactor at $1200{ }^{\circ} \mathrm{C}$. Acetylene curve shows its maximum close to the top of the reactor. This zone corresponds to the maximum of soot production rate as shown by the slope of the curve. Then the decrease in $\mathrm{C}_{2} \mathrm{H}_{2}$ yield is logically accompanied by an increase of soot content along the reactor, in agreement with the precursor role of $\mathrm{C}_{2} \mathrm{H}_{2}$. 


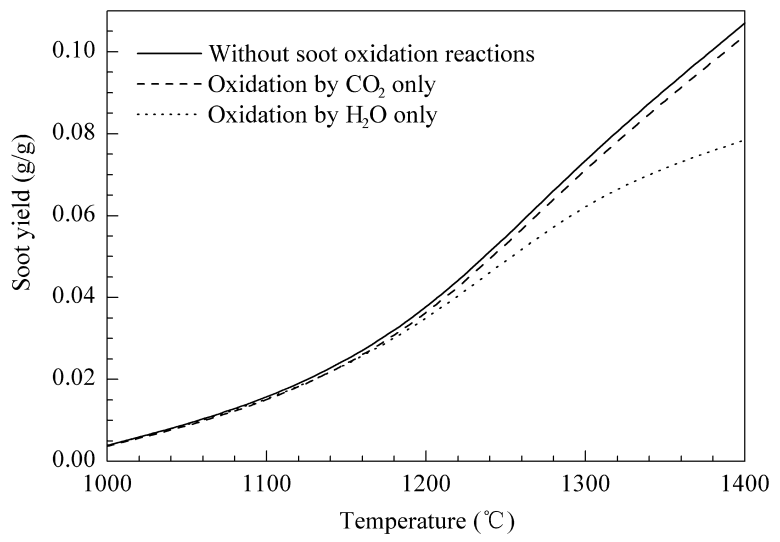

Figure 4. Soot yields versus temperature: modeling at different pyrolysis temperatures

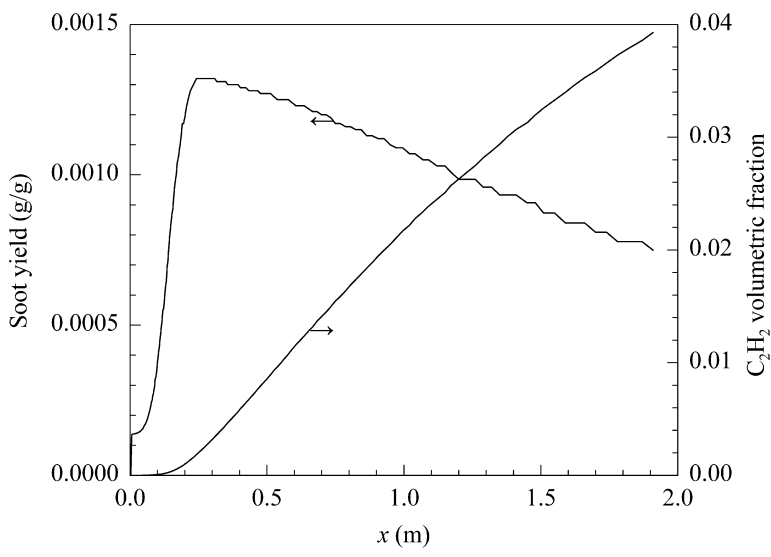

Figure 5. Profile of soot yield and $\mathrm{C}_{2} \mathrm{H}_{2}$ volumetric fraction versus the distance from nozzle during pyrolysis at $1200{ }^{\circ} \mathrm{C}$

(b) Gasification situation

Calculations of soot yield are shown in Figure 6 versus temperature when oxidation reaction are activated and deactivated. We note that the activation of the reaction of oxidation with $\mathrm{CO}_{2}$ caused a very small decrease in the soot yield. Activation of the reaction with water caused an almost complete oxidation of soot at $1300{ }^{\circ} \mathrm{C}$ and $1400{ }^{\circ} \mathrm{C}$.

As previously reported, steam enhances the formation of hydroxyl radicals at high temperature. These radicals may oxidize soot and also consume $\mathrm{C}_{2} \mathrm{H}_{2}$ and therefore cause a decrease in soot production. The issue here is to distinguish the effect of steam on the oxidation of soot through the reforming of $\mathrm{C}_{2} \mathrm{H}_{2}$ and through the direct oxidation by $\mathrm{H}_{2} \mathrm{O}$.

The profiles of $\mathrm{C}_{2} \mathrm{H}_{2}$ volumetric fraction and the soot yield through the reactor at $1200{ }^{\circ} \mathrm{C}$ have been plotted in Figure 7 in three situations:

(i) without steam: this corresponds to the situation in which the production of soot is at its highest level.

(ii) with steam and deactivation of the steam gasification reaction: in this situation only the reforming of $\mathrm{C}_{2} \mathrm{H}_{2}$ occurs;

(iii) with steam and activation of the steam gasification reaction: in this situation both the decrease of soot production through the reforming of $\mathrm{C}_{2} \mathrm{H}_{2}$ and through the direct oxidation of soot by steam may occur.

Comparing (i) and (ii) shows that the presence of steam leads to a slight decrease of $\mathrm{C}_{2} \mathrm{H}_{2}$, and subsequently causes a slight decrease in soot production. However the activation of steam gasification in situation (iii) causes a significant soot oxidation. This proves that the oxidation of soot is mainly due to a direct gasification of soot by steam.

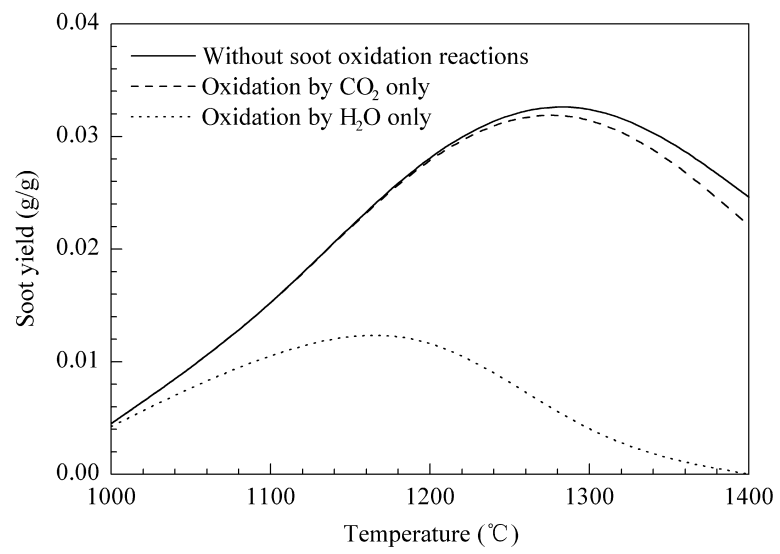

Figure 6. Soot yields versus temperature: modeling at different gasification temperatures

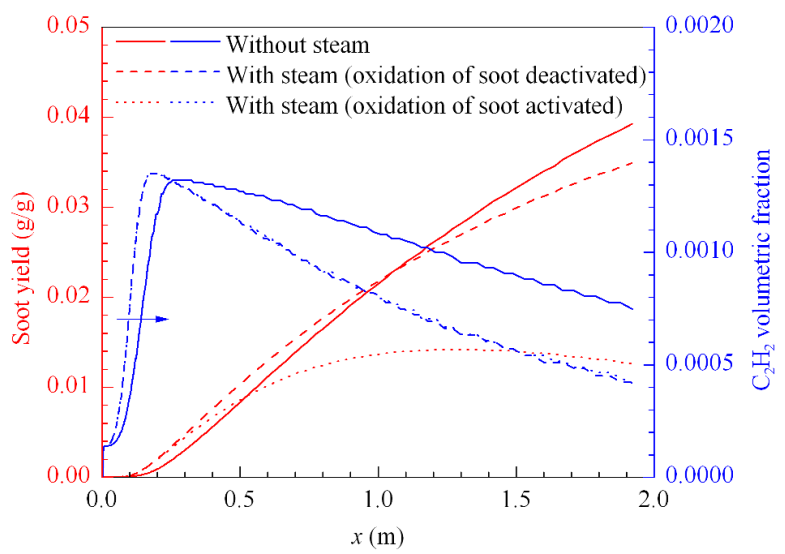

Figure 7. Profile of soot yield and $\mathrm{C}_{2} \mathrm{H}_{2}$ volumetric fraction versus the distance from nozzle during gasification at $1200{ }^{\circ} \mathrm{C}$

(c) Partial oxidation situation

Calculations of soot yield are shown in Figure 8 versus temperature when oxidation reaction are activated and deactivated. None of the three oxidation reactions has a significant effect on soot yield.

As shown in Figure 9, $\mathrm{O}_{2}$ seems to be consumed very quickly at the top of the reactor. Figure 10 shows the soot yield and $\mathrm{C}_{2} \mathrm{H}_{2}$ volumetric fraction along the reactor at $1200^{\circ} \mathrm{C}$ at different $\mathrm{O} / \mathrm{C}$ ratios. It can be noticed that when $\mathrm{O} / \mathrm{C}$ increases $\mathrm{C}_{2} \mathrm{H}_{2}$ decreases in accordance with the $\mathrm{O}_{2}$ consumption (Figure 10) and therefore less soot is produced. According to the model $\mathrm{O}_{2}$ directly acts on $\mathrm{C}_{2} \mathrm{H}_{2}$ yield and thereafter on the amount of soot produced. 


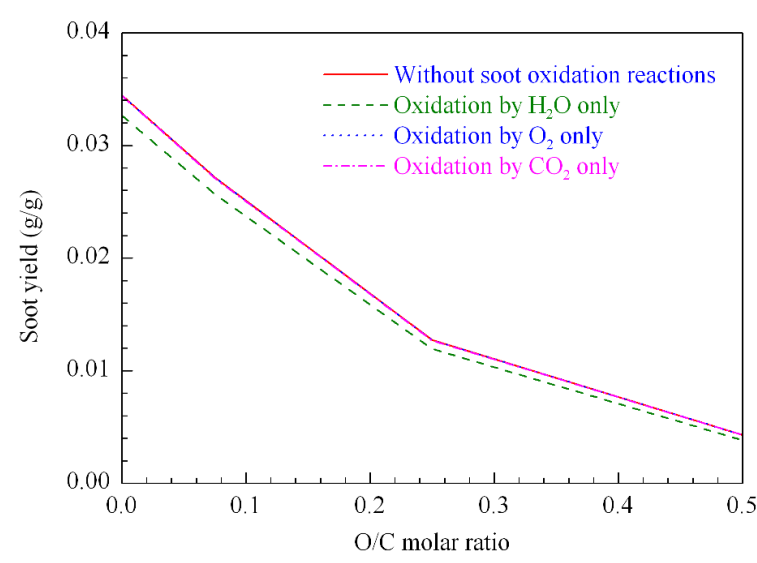

Figure 8. Soot yields versus $\mathrm{O} / \mathrm{C}$ molar ratio at $1200^{\circ} \mathrm{C}$

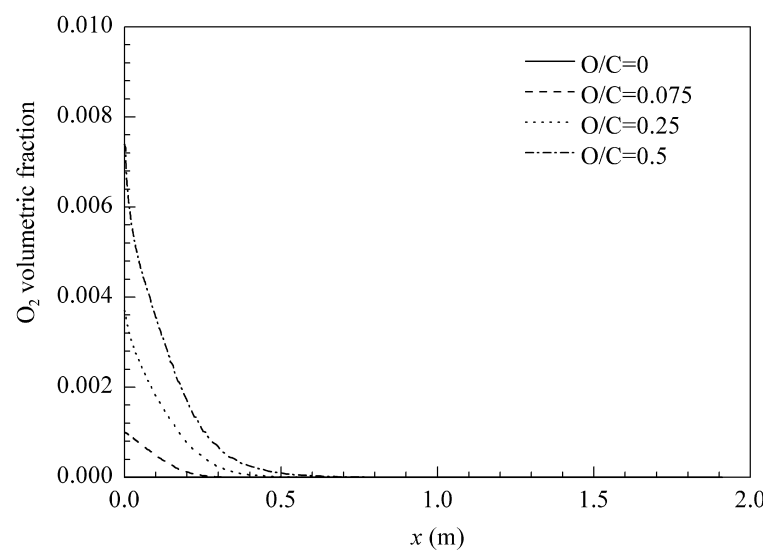

Figure 9. Profile of $\mathrm{O}_{2}$ volumetric fraction versus a distance from nozzle at $1200{ }^{\circ} \mathrm{C}$

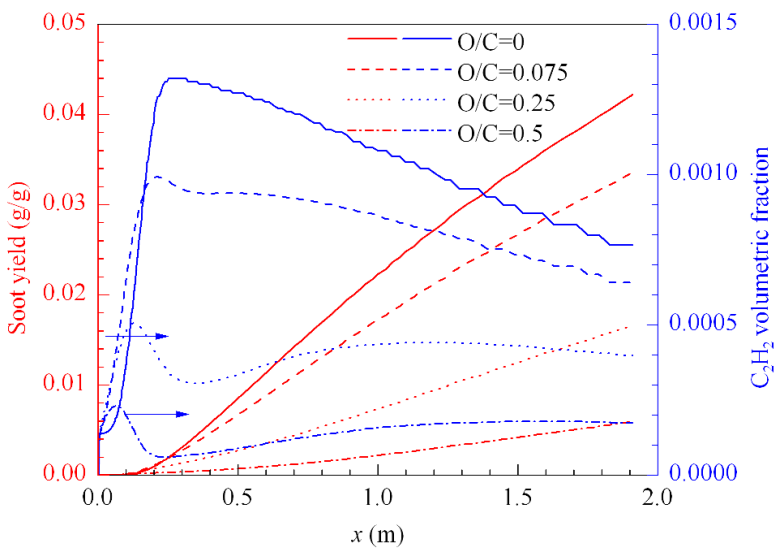

Figure 10. Profile of soot yield and $\mathrm{C}_{2} \mathrm{H}_{2}$ volumetric fraction versus the distance from nozzle during partial oxidation at $1200{ }^{\circ} \mathrm{C}$ - effect of $\mathrm{O} / \mathrm{C}$ molar ratio

To sum up, based on the three considered situations, we found that among the three oxidation reactions only the steam gasification reaction exerts substantially effect on soot. Gasification with $\mathrm{CO}_{2}$ has little effect and oxidation with $\mathrm{O}_{2}$ has no effect.

\section{Conclusions}

The mechanisms of soot formation and oxidation are investigated through experiments under three different atmospheres: inert (pyrolysis), excess of steam (gasification) and in the presence of oxygen (partial oxidation). The proposed semi-empirical model is validated. It is based on detailed chemistry to describe the gas phase, on a single reaction based on $\mathrm{C}_{2} \mathrm{H}_{2}$ concentration to describe soot formation and on three heterogeneous reactions to describe soot oxidation. The approach appears to give satisfactory results. Indeed the amount of the main gases is very accurately predicted and the soot yield is correctly predicted. It has to be highlighted that a single set of identified parameters was used for all simulations.

The study confirms a strong influence of temperature on the mechanisms of soot formation and oxidation. Emphasis was also made on the effect of gasifying agents. Water in excess causes an almost complete gasification of soot at $1300^{\circ} \mathrm{C}$ and $1400^{\circ} \mathrm{C}$. In the partial oxidation situation, at very low concentrations of $\mathrm{O}_{2}$, the soot yield undergoes a slight decrease; an increase of $\mathrm{O}_{2}$ amount greatly reduces the soot yield.

The contribution of each reaction of soot oxidation in the model is identified. $\mathrm{CO}_{2}$ is shown to reduce only small quantities of soot. $\mathrm{O}_{2}$ has no contribution to soot oxidation because it is consumed before soot is formed. Nevertheless, $\mathrm{O}_{2}$ can be consumed by $\mathrm{C}_{2} \mathrm{H}_{2}$ and therefore causes a decrease in soot production. Only steam directly oxidizes the soot and causes their decrease.

\section{Acknowledgements}

The authors gratefully acknowledge the financial support from EnerBio Program of Fondation Tuck France, and express their gratitude to Mr. Bernard AUDUC technician in Ecole des Mines d'AlbiCarmaux for his assistance and contribution to experimental device design and operation.

\section{References}

[1] Cao L Y, Jia Z G, Ji S F, Hu, J Y. J Nat Gas Chem, 2011, 20(4): 377

[2] Liu H L, Hu J H, Wang H, Wang C, Li J Q. J Nat Gas Chem, 2012, 21(4): 374

[3] Zhao L M, Wang H, Qing S, Liu H L. J Nat Gas Chem, 2010, 19(4): 403

[4] Vedal S. J Air Waste Manage Assoc, 1997, 47(5): 551

[5] Bozzano G, Dente M, Faravelli T, Ranzi E. Appl Therm Eng, 2002, 22(8): 919

[6] Shan W J, Yang J L, Yang L H, Ma N. J Nat Gas Chem, 2011, 20(4): 384

[7] Shan W J, Ma N, Yang J L, Dong X W, Liu C, Wei L L. J Nat Gas Chem, 2010, 19(1): 86

[8] Haynes B S, Wagner H G. Prog Energy Combust Sci, 1981, 7(4): 229

[9] Homann H K, Wagner H G. Proc Comb Inst, 1967, 11: 371

[10] Frenklach M, Clary D W, Gardiner W C, Stein S E. Proc Combust Inst, 1985, 20(1): 887

[11] Kiefer J H, Vondrasek W A. Int J Chem Kinet, 1990, 22(7): 747 
[12] Krestinin A V. Khimicheskaya Fizika, 1987, 6(3): 342

[13] Frenklach M, Wang H. Springer, 1994, 59: 165

[14] Griesheimer J, Homann K H. In: Burgess A R, Dryer F L ed. Proceedings of the 27th International Symposium on Combustion. 1998. 1753

[15] Appel J, Bockhorn H, Frenklach M. Combust Flame, 2000, 121(1-2): 122

[16] Richter H, Granata S, Green W H, Howard J B. Proc Comb Inst, 2005, 30(1): 1397

[17] Frenklach M, Wang H. 23rd International Symposium on Combustion, 1990. 1559

[18] Mauss F. [PhD Dissertation]. RWTH Aachen, 1998

[19] Van de Steene L. [PhD Dissertation]. INPT, 1999

[20] Commandré J M. [PhD Dissertation]. INPT, 2002

[21] Cancès J. [PhD Dissertation]. INPT, 2006

[22] Peyrot M, Dupont C, Chen L, Spindler B, Valin S, Cancès J. Biomass Conference Lyon, 2010
[23] Radhakrishnan K, Hindmarsh A C. Technical Report, LLnL report UCLR-ID113855. 1993

[24] Kee R J, Rupley F M, Miller J A. Technical Report, SAND878215B. 1990

[25] Skjøth-Rasmussen M S, Glarborg P, Ostberg M, Johannessen J T, Livbjerg H, Jensen A D. Combust Flame, 2004, 136(1-2): 91

[26] Villermaux J. 2édition Tec \& Doc Lavoisier, 2-85206-759-5. 1993

[27] Alexiou A, Williams A. Fuel, 1995, 74(2): 153

[28] Alexiou A, Williams A. Combust Flame, 1996, 104(1-2): 51

[29] Mendiara T, Domene M P, Millera A, Bilbao R, Alzueta M U. J Anal Appl Pyrol, 2005, 74(1-2): 486

[30] Fletcher T H, Ma J L, Rigby J R, Brown A L, Webb B W. Prog Energy Combust Sci, 1997, 23(3): 283

[31] McEnally C S, Pfefferle L D, Atakan B, Kohse-Höinghaus K. Prog Energy Combust Sci, 2006, 32(3): 247 